\title{
Identification and chromosomal location of major genes for resistance to Pyrenophora teres in a doubled-haploid barley population
}

\author{
T.L. Friesen, J.D. Faris, Z. Lai, and B.J. Steffenson
}

\begin{abstract}
Net blotch, caused by Pyrenophora teres, is one of the most economically important diseases of barley worldwide. Here, we used a barley doubled-haploid population derived from the lines SM89010 and Q21861 to identify major quantitative trait loci (QTLs) associated with seedling resistance to P. teres $\mathrm{f}$. teres (net-type net blotch (NTNB)) and $P$. teres f. maculata (spot-type net blotch (STNB)). A map consisting of simple sequence repeat (SSR) and amplified fragment length polymorphism (AFLP) markers was used to identify chromosome locations of resistance loci. Major QTLs for NTNB and STNB resistance were located on chromosomes $6 \mathrm{H}$ and $4 \mathrm{H}$, respectively. The $6 \mathrm{H}$ locus (NTNB) accounted for as much as $89 \%$ of the disease variation, whereas the $4 \mathrm{H}$ locus (STNB resistance) accounted for $64 \%$. The markers closely linked to the resistance gene loci will be useful for marker-assisted selection.

Key words: disease resistance, Drechslera teres, molecular markers.

Résumé : La rayure réticulée, causée par le Pyrenophora teres, est l'une des plus importantes maladies chez l'orge dans le monde. Les auteurs ont employé une population de lignées haploïdes doublées issues du croisement entre les lignées SM89010 et Q21861 pour identifier un QTL majeur associé à la résistance des plantules face au P. teres f. teres (forme réticulée-NTNB) et au $P$. teres f. maculata (forme tachetée-STNB). Une carte comprenant des microsatellites et des marqueurs AFLP (polymorphismes de longueur des fragments amplifiés) a été employée pour déterminer l'emplacement chromosomique de ces locus de résistance. Des QTL majeurs pour la résistance au NTNB et STNB ont été situés sur les chromosomes $6 \mathrm{H}$ et $4 \mathrm{H}$ respectivement. Le locus sur $6 \mathrm{H}$ (NTNB) expliquait jusqu'à $89 \%$ de la variation alors que le locus sur $4 \mathrm{H}$ en expliquait $64 \%$. Les marqueurs situés à proximité des gènes de résistance seront utiles dans le cadre d'efforts de sélection assistée de marqueurs.
\end{abstract}

Mots clés : résistance aux maladies, Drechslera teres, marqueurs moléculaires.

[Traduit par la Rédaction]

\section{Introduction}

Net blotch, caused by Pyrenophora teres Drechs. f. teres Smedeg., and P. teres Drechs. f. maculata Smedeg., is one of the most widespread diseases of barley (Hordeum vulgare L.) in the major production regions of the world (Mathre 1997). Recently, multiple groups have identified major quantitative trait loci (QTLs) for resistance to net-type net blotch (NTNB), caused by $P$. teres f. teres, with many being on chromosome 6H (Emebiri et al. 2005; Ma et al.
2004; Cakir et al. 2003; and Manninen et al. 2000). Resistance to spot-type net blotch (STNB), which is caused by $P$. teres f. maculata, has not been studied as extensively as resistance to NTNB. However, Williams et al. (1999) identified a single major spot-type resistance gene on the long arm of chromosome 7H and Molnar et al. (2000) identified 2 major STNB resistance genes. In this study, we report on the inheritance and chromosomal location of resistance to NTNB and STNB in the Q21861 × SM89010 $(\mathrm{Q} \times \mathrm{SM})$ doupled-haploid (DH) population.

Received 1 June 2005. Accepted 7 February 2006. Published on the NRC Research Press Web site at http://genome.nrc.ca on 19 July 2006.

Corresponding Editor: P.B. Moens.

T.L. Friesen ${ }^{1}$ and J.D. Faris. United States Department of Agriculture - Agriculture Research Service (USDA-ARS), Cereal Crops Research Unit, Northern Crop Science Laboratory, Red River Valley Agricultural Research Center, Fargo, ND 58105, USA.

Z. Lai. Department of Plant Pathology, Walster Hall, North Dakota State University, Fargo, ND 58105, USA.

B.J. Steffenson. Department of Plant Pathology, Borlaug Hall, University of Minnesota, St. Paul, MN 55108, USA.

${ }^{1}$ Corresponding author (e-mail: friesent@ fargo.ars.usda.gov). 


\section{Materials and methods}

A population of 120 anther culture-derived DH lines was derived from the cross of barley lines Q21861 and SM89010 $(\mathrm{Q} \times \mathrm{SM})($ Steffenson et al. 1995). The $\mathrm{Q} \times \mathrm{SM}$ population was produced and provided by B.G. Rossnagel and K.N. Kao, Crop Development Centre and Plant Biotechnology Institute, Saskatoon, Sask. To determine the gene action conferring single-gene resistance to $P$. teres f. teres, $\mathrm{F}_{2}$ populations were derived from a separate cross between Q21861 and SM89010.

For disease phenotyping, individual lines of the $\mathrm{Q} \times \mathrm{SM}$ $\mathrm{DH}$ population were inoculated with conidia of $P$. teres $\mathrm{f}$. teres isolates 15A (Steffenson and Webster 1992), 0-1 (Weiland et al. 1999), and ND89-19 (Wu et al. 2003) and with $P$. teres f. maculata isolate NZKF2 (Wu et al. 2003). Inoculations were done at the 2- to 3-leaf stage. Individual lines of the $\mathrm{Q} \times \mathrm{SM} \mathrm{DH}$ population were planted along with parents using 3 Conetainers $^{\circledR}$ (Stuewe and Sons, Inc., Corvallis, Oreg.) per line and 3 plants per Conetainer ${ }^{\circledR}$. Plants were placed in racks of 98 consisting of 20 lines and a border of barley plants was used to eliminate any edge effect.

Conidia were grown and harvested as described by Weiland et al. (1999). Conidia were diluted to 4000 spores/ $\mathrm{mL}$, and 2 drops of Tween 20 (polyoxyethylene sorbitan monolaurate) per $100 \mathrm{~mL}$ of inoculum were added to reduce spore clumping. Plants were inoculated until a heavy mist was evident on all leaves, but inoculation ceased before runoff could occur. Plants were then placed in $100 \%$ relative humidity in the dark at $21{ }^{\circ} \mathrm{C}$ for $24 \mathrm{~h}$, and then in a controlled growth chamber under photoperiod conditions of $12 \mathrm{~h}$ light : $12 \mathrm{~h}$ dark at $21{ }^{\circ} \mathrm{C}$. Disease reactions were read at $7 \mathrm{~d}$ post-inoculation. NTNB disease evaluations were done as described using a 1-10 scale (Tekauz 1985), whereas the STNB disease evaluations were done using a 1-9 scale with reaction types 4 and 6 being absent as described for STNB (Tekauz 1985). For P. teres f. teres, lines were classified as resistant if the average disease reaction was 5 or lower and susceptible if higher than 5. Three replicates of 3 cones each were completed for all lines of the population along with the parents. Dominance of resistance to $P$. teres $\mathrm{f}$. teres was investigated using $\mathrm{F}_{2}$ populations of at least 46 individuals for each isolate. Populations were planted, inoculated, and scored for reaction with each of the 3 isolates as described above.

For marker development, DNA was extracted from fresh leaf samples according to Faris et al. (2000) with modifications to sample size. A total of 37 amplified fragment length polymorphism (AFLP) primer combinations were used as described by Vos et al. (1995) with modification to restriction enzymes and adapter sequences. Genomic DNA digestion, adaptor ligation, and preamplification were done as described by Haen et al. (2004). Selective amplification was completed using an IR700- and an IR800-labeled PstI primer with a 3 base extension and an unlabeled MseI primer with a 3 base extension. PCR cycling parameters were done as described by Haen et al. (2004).

AFLP fragments were electrophoresed on $6.5 \% \mathrm{w} / \mathrm{v}$ denaturing polyacrylamide gels $(25 \mathrm{~cm}$ long $\times 0.25 \mathrm{~mm}$ thick $)$ in $1 \times$ Tris-borate EDTA (TBE) buffer (Licor Inc., Lincoln, Neb.) using a Licor Global IR2 system. The same concentra-
Table 1. Average disease reactions to 3 different pathotypes of $P$. teres $\mathrm{f}$. teres in the $\mathrm{Q} \times \mathrm{SM}$ population.

\begin{tabular}{llll}
\hline & \multicolumn{3}{l}{ Average disease reaction } \\
\cline { 2 - 4 } & ND89-19 & $15 \mathrm{~A}$ & $0-1$ \\
\hline Q21861 & $9.33 \pm 0.58$ & $7.0 \pm 2$ & $9.0 \pm 1$ \\
SM89010 & $1.33 \pm 0.58$ & $2.0 \pm 0$ & $1.67 \pm 0.58$ \\
Resistant lines & $1.52 \pm 0.39$ & $1.90 \pm 0.64$ & $1.88 \pm 0.66$ \\
Susceptible lines & $9.61 \pm 0.50$ & $7.88 \pm 1.07$ & $8.78 \pm 1.05$ \\
\hline
\end{tabular}

tion of TBE buffer was also used as the running buffer, and $1 \mu \mathrm{L}$ of each AFLP reaction mixture was loaded into each well. Gels were run for $2.5 \mathrm{~h}$ using the following electrophoresis parameters: voltage, $2000 \mathrm{~V}$; current, $40 \mathrm{~mA}$; power, $50 \mathrm{~W}$; and temperature, $45^{\circ} \mathrm{C}$.

PCR conditions for simple sequence repeats (SSRs) were according to Ramsay et al. (2000). Amplified products were separated on a $40 \mathrm{~cm}$ long $\times 33 \mathrm{~cm}$ wide polyacrylamide gel (CBS Scientific, Del Mar, Calif.) at $70 \mathrm{~W}$ for $2 \mathrm{~h}$. Initially, the entire population was used to score 28 polymorphic SSR primer sets (Ramsay et al. 2000) specific to each of the 14 chromosome arms to assign linkage groups to chromosomes based on previously published maps. Genomic regions harboring resistance genes were targeted with additional SSRs to identify more closely linked markers.

\section{Results and discussion}

Segregation ratios of all markers were tested for fit to the expected 1:1 ratio by $\chi^{2}$ analysis using the computer program QGENE (Nelson 1997). Linkage groups were assembled using the computer program MAPMAKER version 2.0 for Macintosh (Lander et al. 1987) with an LOD > 3.0 and the Kosambi mapping function (Kosambi 1944) as described in Liu et al. (2005).

For QTL analysis, simple interval regression mapping (SIM) (Haley and Knott 1992) and composite interval regression mapping (CIM) were performed to evaluate marker intervals putatively associated with resistance to NTNB and STNB using the computer program Map Manager QTX (Manley et al. 2001). To determine the critical LOD threshold, we executed a permutation test with 5000 permutations. A LOD threshold of about 2.7 in this $\mathrm{DH}$ population yields an experiment-wise significance level of 0.05 .

A total of 123 markers, including 90 AFLPs and 33 SSRs, were mapped in the entire population. A total of 12 markers were either unlinked or formed small linkage groups that could not be assigned to chromosomes. The remaining 111 markers were assembled into linkage groups, which were assigned to barley chromosomes $1 \mathrm{H}-7 \mathrm{H}$.

Average disease reaction types of parents and resistant and susceptible DH lines to $P$. teres f. teres isolates are shown in Table 1 and frequencies of resistant and susceptible $\mathrm{F}_{2}$ and $\mathrm{DH}$ lines are indicated in Table 2. A total of 78 $\mathrm{DH}$ lines were resistant to $P$. teres $\mathrm{f}$. teres (NTNB) isolates 15A, 0-1, and ND89-19 and had reaction types of 4 or lower, whereas 42 lines were susceptible to the same isolates and had reaction types of 6 or higher (Fig. 1). No lines had average disease reactions between 4 and 6 (Fig. 1), indicating that at least 1 major resistance gene was segregating in 
Table 2. Segregation of $\mathrm{Q} 21861 \times \mathrm{SM} 89010 \mathrm{~F}_{2}$ and $\mathrm{DH}$ populations to P. teres $\mathrm{f}$. teres $(\mathrm{NTNB})$ isolates.

\begin{tabular}{lllllll}
\hline Isolate & Resistant $\mathrm{F}_{2}$ & Susceptible $\mathrm{F}_{2}$ & $\chi^{2}(3: 1)$ & Resistant $\mathrm{DH}$ & Susceptible $\mathrm{DH}$ & $\chi^{2}(1: 1)$ \\
\hline 15A & 34 & 12 & 0.029 & 78 & 42 & $10.8^{*}$ \\
$0-1$ & 37 & 12 & 0.0068 & 78 & 42 & $10.8^{*}$ \\
ND89-19 & 38 & 11 & 0.17 & 78 & 42 & $10.8^{*}$ \\
\hline
\end{tabular}

*Significantly different from $1: 1$ at $p=0.05$.

Fig. 1. Histograms showing disease reaction type frequencies of inoculations with $P$. teres f. teres isolates 15A, 0-1, and ND8919 (top) and P. teres f. maculata isolate NZKF2 (bottom).

\section{Reaction Type Distribution in the Barley Q/SM DH Population}

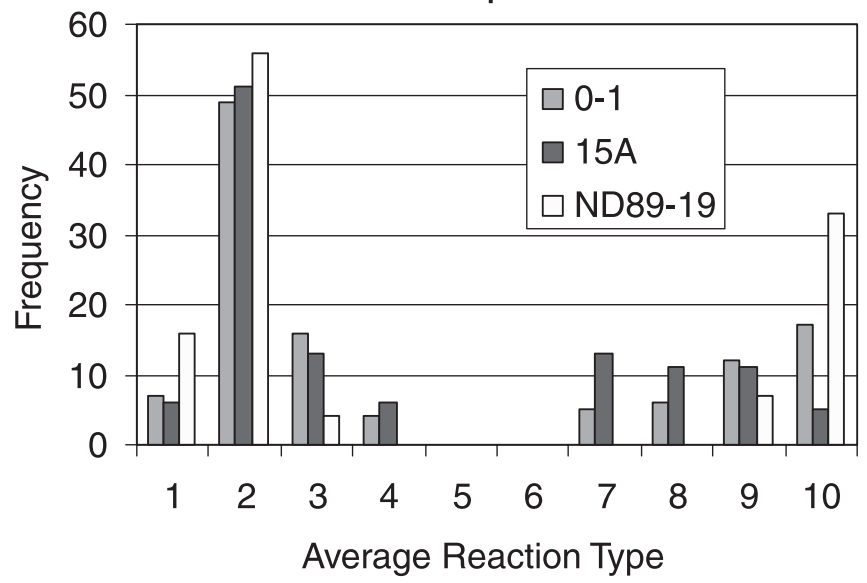

\section{Reaction Type Distribution in the Barley Q/SM DH Population}

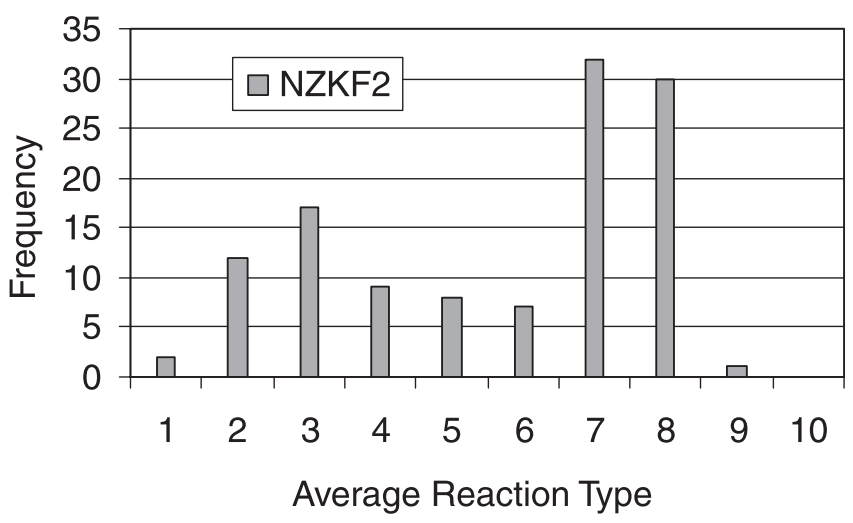

this population. A $\chi^{2}$ analysis of the phenotypic data showed ratios with significant deviation from that expected for a trait controlled by a single gene $\left(\chi^{2}=10.8, p=0.001\right)$ or by 2 genes $\left(\chi^{2}=6.4, p=0.011\right)$.

SSR markers previously shown to map to the short arm of barley chromosome 6H (Ramsay et al. 2000) were associated with the NTNB resistance locus. When reactions to NTNB were scored qualitatively, the SSR marker EBMAC0874 (Ramsay et al.2000) and the AFLP marker M49-P40-650 (Table 3) flanked the resistance locus at distances of 5.9 and $3.4 \mathrm{cM}$, respectively (data not shown). As
Table 3. Pst I and MseI primer combinations each with a 3 base selective extension were used as shown.

\begin{tabular}{ll}
\hline MseI primer sequence & PstI primer sequence \\
\hline M-CAA (M47) & P-AAC (P32) \\
M-CAA (M47) & P-AGC (P40) \\
M-CAC (M48) & P-AGC (P40) \\
M-CAG (M49) & P-AGC (P40) \\
M-CCA (M51) & P-ACT (P38) \\
M-CCA (M51) & P-AGA (P39) \\
M-CCA (M51) & P-AGT (P42) \\
M-CCC (M52) & P-AGA (P39) \\
M-CCG (M53) & P-AAC (P32) \\
M-CCT (M54) & P-AAT (P34)
\end{tabular}

Note: MseI primer sequence, 5'-GATGAGTCCTGAGTAANNN3'; PstI primer sequence, 5'-GACTGCGTACATGCAGNNN-3'.

with the resistance gene locus, markers within this genomic region on $6 \mathrm{H}$ had similar skewed segregation and did not conform to the expected $1: 1$ ratio. This indicates that resistance to $P$. teres $\mathrm{f}$. teres is governed by a single nuclear gene in the $\mathrm{Q} \times \mathrm{SM}$ population.

When phenotypic reactions to $P$. teres $\mathrm{f}$. teres were scored quantitatively, interval regression analysis indicated a major QTL on the short arm of chromosome $6 \mathrm{H}$ associated with resistance, which coincided with the position of the $P$. teres f. teres resistance gene. This QTL peaked between markers EBMAC0874 and M49-P40-650 and explained 84\%-89\% of the phenotypic variation for the 3 isolates (Fig. 2). No other genomic regions significantly associated with resistance were detected for this trait.

Inoculations of $\mathrm{F}_{2}$ populations derived from $\mathrm{Q} \times \mathrm{SM}$ using $P$. teres f. teres isolates 15A, 0-1, and ND89-19 gave resistant-susceptible ratios not significantly different from 3:1 (Table 2), thereby providing further evidence that resistance is governed by a single gene and that it is dominant in nature.

Major resistance genes effective against $P$. teres $\mathrm{f}$. teres (NTNB) have previously been identified on chromosome $6 \mathrm{H}$ by at least 2 other groups (Cakir et al. 2003 and Manninen et al. 2000) using different resistant sources. Both Cakir et al. (2003) and Manninen et al. (2000) found that a major QTL on chromosome $6 \mathrm{H}$ accounted for $65 \%$ of the disease variation. Cakir et al. (2003) showed that Bmag0173 was the marker most closely associated with NTNB resistance. The work presented here also shows Bmag0173 to be closely associated with NTNB resistance. It is possible that the $6 \mathrm{H}$ resistance gene harbored by SM89010 is the same as that found in the 2 previous studies. It is also possible that the gene reported by Cakir et al. (2003) and the one reported in this work are different but closely linked. Further population 
Fig. 2. Composite interval regression maps of barley chromosomes $4 \mathrm{H}$ and $6 \mathrm{H}$ indicating the associations of markers with reaction to P. teres f. maculata isolate NZKF2 and P. teres f. teres isolates 15A, 0-1, and ND89-19. The dotted line represents the LOD significance threshold of 2.7. The LOD value for the largest QTL peak is given along the bottom horizontal line. A centimorgan (cM) scale is indicated to the left of the graphs. Markers with segregation ratios that significantly deviated from 1:1 are indicated with asterisks $(* p<0.05 ; * * p<0.01 ; * * * p<0.005 ; * * * * * p<0.0005)$.

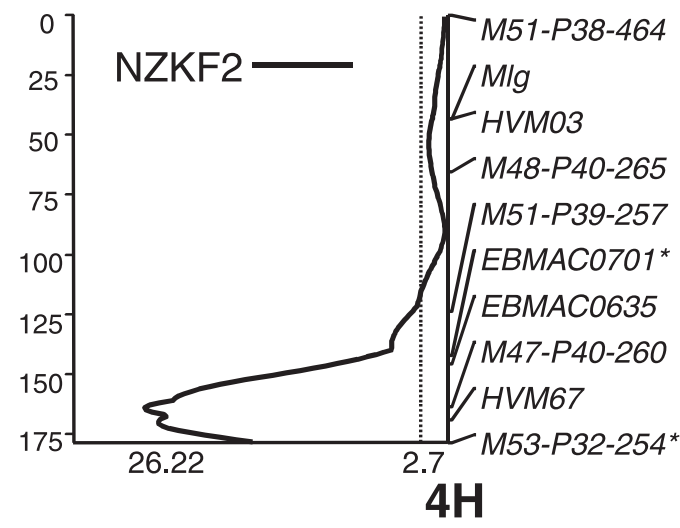

development and allelism tests are needed to confirm whether these are the same or closely linked genes.

Average disease reactions of Q21861 and SM89010 to STNB caused by $P$. teres f. maculata were 2.67 and 6.33, respectively. The DH population had an average disease reaction of 5.4 , but reactions ranged from 1 to 8.3 (Fig. 1). The observed quantitative nature of resistance to STNB precluded inference of individual DH lines as either resistant or susceptible. Therefore, only QTL analysis was used to identify genomic loci associated with resistance to STNB. Interval regression analysis indicated a major QTL on the long arm of chromosome $4 \mathrm{H}$ associated with resistance to STNB caused by P. teres f. maculata isolate NZKF2 (Fig. 2). This QTL peaked between markers M47-P40-260 and HVM67 and explained $64 \%$ of the phenotypic variation. No other genomic regions significantly associated with resistance were detected.

The spot form of $P$. teres (STNB) has had little impact in the barley growing regions of the northern Great Plains of the USA. However, severe disease outbreaks have occurred in both Canada and Western Australia, where losses in grain yield of up to $25 \%$ were estimated (Khan and Tekauz 1982). Little research has been done on the identification of STNB resistance genes. To our knowledge, the resistance gene found in line Q21861 is the first STNB resistance gene identified on barley chromosome $4 \mathrm{H}$. Although major and minor resistance genes have been identified on $4 \mathrm{H}$ (Steffenson et al. 1996; Richter et al. 1998; Spaner et al. 1998; and Raman et al. 2003), all are associated with NTNB and none can clearly be shown to correlate with the locus identified in this study.

In this study, we have identified 2 different major resistance genes, one on barley chromosome $6 \mathrm{H}$ and effective against multiple pathotypes of $P$. teres $\mathrm{f}$. teres (NTNB), the other on chromosome $4 \mathrm{H}$ and effective against $P$. teres $\mathrm{f}$. maculata (STNB). SM89010 harbors the NTNB resistance gene and Q21861 harbors the STNB resistance gene. Therefore, lines within this population harboring both resistance genes could be effectively used to simultaneously introgress both genes into breeding lines. Molecular markers flanking these genes will also be useful in marker-assisted selection programs for more efficient introgression of these genes.

\section{Acknowledgements}

The authors thank Danielle Holmes and Philip Meyer for technical assistance, B.G. Rossnagel for providing the mapping population and Andy Tekauz for providing fungal isolates. This research was supported by funding from the American Malting Barley Association along with USDAARS CRIS projects 5442-22000-030-00D and 5442-21000037-00D.

\section{References}

Cakir, M. Gupta, S., Platz, G.J., Ablett, G.A., Loughman, R., Emebiri, L.C., et al. 2003. Mapping and validation of the genes for resistance to Pyrenophora teres f. teres in barley (Hordeum vulgare L.). Aust. J. Agric. Res. 54: 1369-1377.

Emebiri, L.C., Platz, G., and Moody, D.B. 2005. Disease resistance genes in a doubled haploid population of two-rowed barley segregating for malting quality attributes. Aust. J. Agric. Res. 56: 49-56.

Faris, J.D., Haen, K.M., and Gill, B.S. 2000. Saturation mapping of a gene rich recombination hot spot region in wheat. Genetics, 154: 823-835.

Haen, K.M., Lu, H., Friesen, T.L., and Faris, J.D. 2004. Genomic targeting and high resolution mapping of the Tsnl gene in wheat. Crop Sci. 44: 951-962.

Haley, C.S., and Knott, S.A. 1992. A simple regression method for mapping quantitative trait loci in line cross using flanking markers. Heredity, 69: 315-324.

Khan, T.N., and Tekauz, A. 1982. Occurrence and pathogenicity of Drechslera teres isolates causing spot type symptoms on barley in Western Australia. Plant Dis. 66: 423-425.

Kosambi, D.D. 1944. The estimation of map distances from recombination values. Ann. Eugen. 12: 172-175.

Lander, E.S., Green, P., Abrahamson, J., Barlow, A., Daly, M.J., Lincoln, S.E., and Newberg, L. 1987. MAPMAKER: an interactive computer package for constructing primary genetic linkage maps of experimental and natural populations. Genomics, 1: 174-181. 
Liu, Z.H., Anderson, J.A., Hu, J.G., Friesen, T.L., Rasmussen, J.B., and Faris, J.D. 2005. A wheat intervarietal genetic linkage map based on microsatellite and target region amplified polymorphism markers and its utility for detecting quantitative trait loci. Theor. Appl. Genet. 111: 782-794.

Ma, Z.Q., Lapitan, N.L.V., and Steffenson, B.J. 2004. QTL mapping of net blotch resistance genes in a doubled population of six-rowed barley. Euphytica, 137: 291-296.

Manley, K.K., Cudmore, Jr., R.H., and Meer, J.M. 2001. Map Manager QTX, cross platform software for genetic mapping. Mamm. Gen. 12: 930-932.

Manninen, O., Kalendar, R., Robinson, J., and Schulman, A.H. 2000. Application of BARE-1 retrotransposon markers to the mapping of a major resistance gene for net blotch in barley. Mol. Gen. Genet. 264: 325-334.

Mathre, D.E. 1997. Compendium of barley diseases. 2nd ed. American Phytopathological Society, St. Paul, Minn.

Molnar, S.J., James, L.E., and Kasha, K.J. 2000. Inheritance and RAPD tagging of multiple genes for resistance to net blotch in barley. Genome, 43: 224-231.

Nelson, J.C. 1997. Q-GENE: software for marker-based genomic analysis and breeding. Mol. Breed. 3: 239-245.

Raman, H., Platz, G.J., Chalmers, K.J., Raman, R., Read, B.J., Barr, A.R., and Moody, D.B. 2003. Mapping of genomic regions associated with net form of net blotch resistance in barley Aust. J. Agric. Res. 54: 1359-1367.

Ramsay, L., Macaulay, M., degli Ivanissevich, S., MacLean, K., Cardle, L., Fuller, J., et al. 2000. A simple sequence repeatbased linkage map of barley. Genetics, 156: 1997-2005.

Richter, K., Schondelmaier, J., and Jung, C. 1998. Mapping of quantitative trait loci affecting Drechslera teres resistance in barley with molecular markers. Theor. Appl. Genet. 97: 1225-1234.
Spaner, D., Shugar, L.P., Choo, T.M., Falak, I., Briggs, K.G., Legge, W.G., et al. 1998. Mapping of disease resistance loci in barley on the basis of visual assessment of naturally occurring symptoms. Crop Sci. 38: 843-850.

Steffenson, B.J., and Webster, R.K. 1992. Pathotype diversity of Pyrenophora teres f. teres on barley. Phytopathology, 82: 170 177.

Steffenson, B.J., Jin, Y., Rossnagel, B.G., Rasmussen, J.B., and Kao, K. 1995. Genetics of multiple disease resistance in a doubled-haploid population of barley. Plant Breed. 114: 50-54.

Steffenson, B.J., Hayes, P.M., and Kleinhofs, A. 1996. Genetics of seedling and adult plant resistance to net blotch (Pyrenophora teres f. teres) and spot blotch (Cochliobolus sativus) in barley. Theor. Appl. Genet. 92: 552-558.

Tekauz, A. 1985. A numerical scale to classify reactions of barley to Pyrenophora teres. Can. J. Plant. Pathol. 7: 181-183.

Vos, P., Hogers, R., Bleeker, M., Reijans, M., van de Lee, T., Hornes, M., et al. 1995. AFLP: a new concept for DNA fingerprinting. Nucleic Acids Res. 23: 4407-4414.

Weiland, J.J., Steffenson, B.J., Cartwright, R.D., and Webster, R.K. 1999. Identification of molecular genetic markers in Pyrenophora teres f. teres associated with low virulence on 'Harbin' barley. Phytopathology, 89: 176-181.

Williams, K.J., Lichon, A., Gianquitto, P., Kretschmer, J.M., Karakousis, A., Manning, S., et al. 1999. Identification and mapping of a gene conferring resistance to the spot form of net blotch (Pyrenophora teres f. maculata) in barley. Theor. Appl. Genet. 99: 323-327.

Wu, H.-L., Steffenson, B.J., and Zhong, S. 2003. Genetic variation for virulence and RFLP markers in Pyrenophora teres. Can. J. Plant Pathol. 25: 82-90. 